\title{
Law Enforcement Of Fraud Through Electronic Media
}

\author{
I Nyoman Gede Sugiartha, A.A.Sagung Laksmi Dewi and I Made Minggu Widyantara \\ Faculty of Law, Universitas Warmadewa, Denpasar-Indonesia \\ nyomansugiartha14@gmail.com, laksmiidewi29@gmail.com, mademinggu21@gmail.com
}

Published: 25/02/2021

How to cite:

Sugiartha, I. N. G., Dewi, A. A. S. L., \& Widyantara, I. M. M. (2021). Law Enforcement Of Fraud Through Electronic Media. Sociological Jurisprudence Journal. 4(1). Page 61 - 67. https://doi.org/10.22225/scj.4.1.2570.61-67

\begin{abstract}
Fraud case of using electronic media often occur in Indonesia at the moment. This illustrates that the community is remain very vulnerable in carrying out activities related to the electronic media. For this reason, it is necessary to undertake a research regarding to criminal offenses using electronic means, especially against criminal fraud. This obsolutely obtains an attention to investigate about legal policies of fraud through electronic media, and criminal penalty of fraud perpetrators through Electronic Media. This study aims to find out about the criminal sanctions of fraud perpetrators through electronic media and to find out the legal policies of criminal acts of fraud through electronic media. This research used the Normative research method. Fraud in Indonesia as regulated in article 378 of the Criminal Code, while fraud by spreading false news which harms consumers in electronic transactions through online or electronic media is regulated in article 28 Paragraph (1) of the Information and Electronic Transaction Act. The spread of hoaxes is equated with acts of deception in the real world as stipulated in article 378 of the Criminal Code. Fraud criminal penalty through electronic media may be subject to multiple articles against a criminal act that fulfills the elements of a criminal offense as regulated in article 378 of the Criminal Code and meets the elements of a criminal act article 28 paragraph (1) of the Information and Electronic Transaction Act.
\end{abstract}

Keywords: Criminal Penalty; Electronic Media; Perpetrator.

\section{INTRODUCTION}

The Indonesian state in the form of a unitary state, based on law (rechstaat), is not based on power (machstaat). The main priority in the life of the state is to put the law above for all levels of nation, one of the efforts is to practice the progress in the field of law and create a justice, legal clarity, order, and a society that understands and complies with the law. Law enforcement must be in accordance with applicable regulations and based on the Pancasila and the 1945 Constitution of the Republic of Indonesia. (Kurnia, 2016)

Modern life which is supported by communication technology makes it easy for people to absorb and share various information to individuals and the public. Electronic media is undeniably indeed facilitating the activities of the global community and one of them is in business transactions, especially financial business in addition to other businesses (Rahardjo, 2002) Coinciding with technological advances and public information is made to keep abreast of all developments that are happening. In communicating and socializing, it is really necessary for technological and information advancements, because of this it makes it easier for the public in all aspects, that is communicating in new ways, selling in new ways, and doing business without time and place limitation. This opens the eyes of the public with a new world whose development is very rapid. The internet is one method that is very often used in this matter because the internet is one of the technological developments that has changed the world from year to year.

The most common crime in electronic media, is fraud, where this crime offers a variety of things consisting of business transactions, buying and selling goods or services by applying unreasonable 
prices or below normal. However, this is not easy to avoid because this transaction has become a trend, therefore this trend opens a chance to irresponsible person, in which these persons dare to break the rules in order to benefit and enrich themselves or others. Online business makes it easy for fraudsters to carry out their actions. (Chazawi, 2015). Indonesia sits in 12th position in the rank of countries in the Asia Pacific region that have malicious activities based on country, but in the following years in 2009-2010 its rank jumped rapidly, and immediately appear at number 9 between Australia in rank 8 and the Philippines in rank 10. In total, for the APJ (Asia Pacific Japan) region, Indonesia contributes 3\% of the total regional malicious activities, it is not only in activities with malicious intentions that the rank of Indonesia is rised. In Top Web-based Attack rank which based on location throughout 2009-2010 Indonesia in 2012 has been ranked 8 up one rank since 2009 or 3\% of the total region (Lay, 2011). The Head of Unit V of Cyber Crime Sub Directorate of the Jakarta Metropolitan Police AKBP Dhany Aryanda said that during 2019 there were 2,300 online fraud reporting with social engineering actions (Mahardhika, 2020). In Indonesia, based on data from the Ministry of Communication and Information Technology, there have been 16,678 reports coming into the site. "Data as of September 11, 2018," Acting Head of the Public Relations Bureau of the Ministry of Communication and Informatics Ferdinandus Setu, when contacted Kompas.com, Tuesday (11/09/2018). Of all the reports that came in, nearly 14,000 of them were crimes in the form of online transaction fraud. Meanwhile, the rest are cases of investment fraud, extortion, online prostitution, and other crimes such as fake lottery, bribery, and corruption (Arnani, 2018). This fact illustrates that the development of technology and information such as a double-edged sword, because in addition to contribute in improving the welfare, progress, and human civilization, as well as an effective means of acting against the law and the development of a new crime mode (Ramli, 2004). Law enforcement that has not been firm and clear in truth is the trigger for fraud perpetrators in committing criminal acts of fraud through this electronic media. Legal problems that are often faced in online fraud are when related to the delivery of information, communication, and or electronic transactions, namely in terms of evidence and matters relating to legal actions carried out through the electronic system (Suhariyanto, 2012)

Referring to the description above, it can be concluded that frauds will always exist because of the rapid development of technology and ways of communication where crime is increasingly sophisticated and advanced as well. Evidenced by the media used, crime will have many ways to do it. Therefore, fraud using electronic media requires a more specific understanding/comprehending as well as any regulations that are used in the effort to follow up these acts of crime by law enforcement officials and efforts to overcome them.

Referring to the background above, the problem statement can be stated as follows:

1. What is the legal policy on fraud through electronic media?

2. How is law enforcement against fraud perpetrators through electronic media?

The objectives of this study are as follows:

1. To find out the legal policy of fraud through electronic media.

2. To find out the criminal sanctions of fraud perpetrators through electronic media.

The method of writing scientific papers is the normative method that is by examining existing legal library materials. Sources of legal materials used were taken from library research in the form of:

1. Sources of primary legal materials based on the Criminal Code and Act No. 11 of 2008 concerning Electronic Transaction and Information

2. Sources of secondary legal materials are taken from books, theses, journals and documents that can support the completion of this research.

\section{RESULT AND DISCUSSION}

\section{The Policy Of Criminal Law Action Through Electronic Media}

Fraud crime has the basic word that is 'tipu' deception, that is, actions/perfromance or words that are not true/honest with the intention of plunging, tricking or seeking profit. While fraud is a procedure, a way, a step in cheating. Fraudulent actions, so called because an individual has committed an act that is 
not commendable where the action is to spread or speak things that are not true based on a news, incident, message, and other things with a specific purpose to benefit one party. Deceptive actions taken by someone to give the view that the thing conveyed or disseminated is true and in accordance with the facts, this deception is aimed at gaining the trust of others or society and then harming the person and society. In this community fraud is very often the case because the perpetrators have demands to meet their own needs, then all means will be halted, including cheating with the aim of meeting their own needs and making a profit.

Supporting factors, which cause fraud crime such as technological advances that open up opportunities for actors in launching their actions, are caused by several factors such as: entangled in debt, uncontrolled desire for luxury goods, deviations in behavior, economic conditions and so forth. As the purpose of law is to force someone to obey and comply the applicable law. Besides that, someone who commits this fraud is sometimes motivated to carry out this act continuously and repeatedly because the perpetrator is motivated to get rich quickly and think that other people are stupid because he thinks others are easy to be fooled or cheated. Article 378 of the Criminal Code stipulates fraud in general form, as well as in 20 articles which damage various forms of fraud against property, each of which has a special name listed in Chapter XXV Book II of the Criminal Code. Fraud according to article 378 of the Criminal Code by Moeljatno as follows: "Whoever intends to benefit themselves or others unlawfully by using false names or fake hoednigheids with deception, or a series of lies, moves others to hand over something to him, or to give debt or write off receivables, threatened with fraud, with a maximum imprisonment of four years. "(Moeljatno, 2007). Further based on the formulation of Article 378 of the Criminal Code R. Sugandhi put forward the notion of fraud that: "Fraud is the act of someone with a series of lies, false names and false circumstances with the intention of benefiting oneself with no rights. A series of lies is the arrangement of lies which are arranged in such a way that is the story of something that seems to be true. "(Sugandhi, 1980). The elements of the criminal act of fraud benefit oneself, cause harm to others, deceive others to give or do something by using fraudulent efforts by violating the applicable legal rules as stated in line in Article 378 of the Criminal Code is the nature of the crime fraud itself. Article 378 of the Criminal Code concerning fraud. Based on the aforementioned formulation, then the Criminal Act of Fraud has a basic element, namely: with the intention to benefit oneself or others illegally. In a simple explanation of this element that is the closest goal of the actor means the actor wants to benefit. The advantage is the main goal of the offender by going against the law, if the offender still needs other actions, then the intent cannot be fulfilled. Thus the intent is intended to benefit and against the law, so that the perpetrators must know that the benefits which become their objectives must be against the law. By using one or more fraudulent activators (fake names, false dignity / false circumstances, deception and a series of lies). The point is that the nature of fraud as a crime is determined by the ways in which the perpetrators move others to hand over the goods (Soerodibroto, 1992). Furthermore according to Moeljatno, the elements of fraud are as follows:

1. There is someone who is persuaded or moved to surrender an item or make a debt or write off a debt. The goods or money are handed over by those who have it by way of deception. The items delivered do not always have to belong to themselves, but also to others.

2. The fraudster intends to benefit himself or others without rights. From that purpose it turns out that the aim is to harm the person who surrenders the item.

3. Those who are victims of fraud must be mobilized to hand over the goods by:

- Submission of goods must be the result of deception.

- Fraudster must deceive the victim with a regulated mind

In Article 378 of the Criminal Code (Moeljatno, 2002).

As for the movers used to move others people are as follows:

1. False Names, in this case different names from names that are actually despite the small difference. It is different if the fraudster uses the name of someone else who is the same as his own name, then he can be blamed for guile or arrangement of lies.

2. the action that is undertaken in such a way, so that the action gives rise to a belief or belief in the truth of something to someone else. If this quile is not words but deeds or actions. 
3. False dignity/circumstances, the use of dignity or false circumstances is when a person gives a statement that he is in a certain situation, in which case it gives rights to people who are in that situation.

4. A series of lies, just a few words of lie are considered not enough as a driving tool. This was confirmed by Hoge Raad in his arrest on March 8, 1926, that:

"There is a series of lies if between those lies there is such a relationship and one lie complements the other lies so that they reciprocally give rise to a false image as if it were a truth."

The series of that lies must be spoken in a structured manner, so that it is a story that can be accepted logically and correctly. Thus the word one reinforces / justifies the words of others.

Fulfilling the needs or benefits that result in someone committing fraud therefore fraud is very common in the community. Electronic Transactions are legal actions in which an agreement between a seller and a buyer is carried out using media such as computers, gadgets, internet networks or other electronic media such as those based on Electronic Transaction and Information Act. Legal ties or legal relationships conducted electronically where there are buying and selling activities in it by combining networks of electronic-based media such as law and gadgets with network-based communication laws, namely the internet, is the definition of these electronic transactions. Electronic trade contracts, electronic trade transactions and web contracts are other terms that are often used in electronic transactions (e-commerce). So that electronic transactions are trade transactions between sellers and buyers by utilizing electronics as a medium and the internet as a liaison network between the media used, so that the process of ordering goods, payment for transactions that take place until the delivery of goods is communicated through electronic media connected to the internet. (Massudilawe, 2008)

Fraud in electronic transactions or what is often referred to as online fraud is a fraud crime that refers to activities that use computers, gadgets, and everything that uses the internet network. Electronic transactions have their own nature or characteristics, including:

1. Transactions without borders, in which an online business that has consumers and develops in various places that have very large capital without any restrictions.

2. Transactions without names, i.e. transactions without the need for face-to-face contact, identitiy or identification between the seller and buyer.

3. Digital and non-digital goods or products, i.e. the products sold are digital products such as; software that can be downloaded via the internet and non-digital such as electronic goods and daily necessities such as clothing, vehicles, and others.

4. Intangible products or goods, i.e. products that do not have a form such as files, software, or ideas to be sale on the internet.

The scheme of fraud that in electronic transactions often occurs on internet sites, chat rooms, advertisements, and e-mails, where the perpetrators have a role in offering products/goods to potential victims where the product or goods actually never existed, communicating with them the nature of plundering victims to the point of causing losses by taking or moving victims' funds or other items without the victim's knowledge in the possession of the perpetrators. The meaning above, defines fraud through electronic media that is connected to the internet network has the same understanding as ordinary fraud but fraud in electronic transactions uses one or more media components and exsisting components that are on the internet such as sites, chat rooms and email. (Danrivanto, 2017)

Act No. 11/2008 concerning Electronic Transactions and Information The Electronic Transactiona and Information Act has not specifically regulated fraud through electronic media, the article specifically used is article 378 of the Criminal Code which concluded that anyone with the intention of benefiting themselves or other parties with against and also formulate others to give up everything they have, and eliminate receivables will be sentenced to a maximum of 4 years in prison.

Though the Electronic Transactiona and Information Act does not specifically regulate fraud committed in electronic media, but there is a consumer loss in transactions in electronic media as concluded from Article 28 paragraph (1) of the Electronic Transactiona and Information Act where everyone who spreads invalid news and plunges others at a loss. Then the perpetrators who violate the rules of Article 28 paragraph 1 of the Electronic Transactiona and Information Act can be threatened 
with criminal acts as in Article 45A paragraph 1 of Act No. 19 of 2016, namely, those who deliberately spread invalid news as referred to in Article 28 paragraph (1) of the Electronic Transactiona and Information Act can be sentenced to a maximum of 6 years in prison and a maximum of 1 billion rupiah in fines.

It can be concluded that Article 378 of the Criminal Code and Article 28 paragraph (1) of the Electronic Transactiona and Information Act regulates different things, namely, Article 378 of the Criminal Code concerning fraud and Article 28 paragraph (1) of the Electronic Transactiona and Information Act regulates invalid or false news which results in losses to consumers in the transaction in electronic media.

Related to the formulation of Article 28 paragraph (1) of the Electronic Transactiona and Information Act which uses sentences to spread invalid and false news, which also actually has similarities with the provisions of article 390 of the Criminal Code, although with a slightly different formula of Article 28 paragraph (1) concluded that the parties which aims to benefit oneself or other parties by violating applicable law, by broadcasting false news, and causing the price of goods and services to become unclear, will be jailed for a maximum of two years and eight months. In this case the sentence broadcasts false news and also the losses incurred are specifically regulated. When compared to these rules have in common that can cause harm to consumers. However, the formulation of Article 28 paragraph (1) of the Electronic Transactiona and Information Act does not require an element of selfbenefit or other parties as stipulated in Article 378 of the Criminal Code concerning fraud.

IIn accordance with the elements that have been fulfilled from the rules of Article 28 paragraph (1) of the Electronic Transactiona and Information Act and Article 378 of the Criminal Code, law enforcement can impose multiple articles on perpetrators of fraud that have fulfilled the requirements of the two articles.

\section{Criminal Penalty Of Fraud Perpetrators Through Electronic Media}

IThe imposition of criminal penalty is the goal of punishment itself, to provide a deterrent and justice effect for the offender. The purpose of Criminalization according to Wirjono Prodjodikoro is as follows: 1. To frighten people not to commit crimes either by scaring people (generals preventive) or by scaring certain people who have committed crimes so that in the future they will not commit any crimes again. 2. To educate or improve those who commit crimes to have a good character so that it benefits the community. (Prodjodikoro, 1998). Van Hamel said that: the crime is a straf according to positive law today, is a special suffering, which has been imposed by the power authorized to impose a crime on behalf of the state as the person in charge of public order for an offender, that is solely because the person has violated a regulation that must be enforced by the State (Lamintang, 1984). Conditions for the imposition of criminal penalty against fraud perpetrators through electronic media can be reviewed from the fulfillment of all elements and objectives of the commission of the crime based on the fact that the fraud ss done intentionally and consciously will be criticized by the applicable law. The Elements contained in the Act in question are as follows:

IIThe elements contained in Article 28 paragraph (1) of the ITE Law are objective elements, namely acts that have spread invalid and untrue news and from this act have caused harm to consumers who have transacted in electronic media. The subjective element, namely the act of intentionally spreading invalid news that causes harm to consumers who transact in electronic media and the existence of elements against the law without rights.

IIIWith the fulfillment of these elements, a criminal penalty will be imposed where the actions must be accounted for by the actions carried out. Criminalization is aimed at preventing the emergence of the same criminal act by enforcing applicable law, so it must be applied properly and clearly. Evidence of criminal liability against an offender who has committed a criminal offense if it meets the requirements, namely the offender has committed a crime, the offender has been legally competent or mature according to the law and can be held accountable and able to take responsibility for the actions that have been carried out and the proof required after the fulfillment of all elements of the criminal offense, so there is a need for evidence to substantiate evidence of a criminal offense that has been committed, then a minimum of two pieces of evidence is needed as a tool to convince a judge of a case from a crime that is being handled. 
IVIn deciding a criminal act that is responsible for someone should have a nature that is against the law. At this time, the Electronic Transaction and Information Act does not specifically contain the offense of fraud, and Article 28 paragraph (1) of the Electronic Transaction and Information Act is still general in nature with the emphasis on spreading invalid news and causing damage to consumers who transact through electronic media. (Soesilo, 1991) Where Act No. 11 of 2008 concerning information and electronic transactions has not specifically regulated fraud through electronic media, so far the criminal act of fraud has only been regulated in Article 378 of the Criminal Code

VAlthough the Electronic Transaction and Information Act does not specifically regulate fraud through electronic media in which this is very necessary because this is a very often case and has caused many losses, in electronic transactions there are provisions in Article 28 paragraph (1) of the Electronic Transaction and Information Act namely parties intentionally and without permission spreading invalid or doubtful news and plunging into a loss for consumers in the transaction, this crime can be sentenced

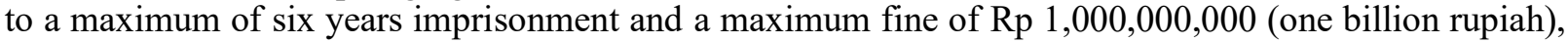
in accordance with Article 45 paragraph (2) of the Electronic Transaction and Information Act.

VIThis legal policy requires carefulness or thoroughness of law enforcers in determining the use of articles that meet the requirements for fraud via electronic media, in practice a crime that has fulfilled the requirements for criminal fraud is specifically involved in the regulation. in article 378 of the Criminal Code and has broadcast invalid or false news as regulated in Article 28 paragraph (1) of the 2008 Electronic Transaction and Information Act, then the elements of fraud through electronic media have been fulfilled, then law enforcement can use both of these articles and sentence according to the provisions of these articles.

\section{CONCLUSION}

For the ruling law specifically for fraud currently only in Article 378 of the Criminal Code, while disseminating invalid or false news to cause harm is regulated in Article 28 paragraph (1) of the Electronic Transaction and Information Act. Dissemination of this hoax with the real world fraud stipulated in Article 378 of the Criminal Code so that all types of electronic transactions that harm one of the parties can be used as legal evidence in the name of the law.

The application of criminal penalty can be subject to multiple articles in general as contained in Article 378 of the Criminal Code, besides that it can also be subject to Article 28 paragraph (1) of the Electronic Transaction and Information Act, if the elements have been fulfilled then law enforcement can use both of these articles the enforcement of the panel of judges' considerations also includes matters which are burdensome and mitigating in criminal acts related to perpetrators. Besides being criminally, the perpetrators can also be sued for compensation by the victim through civil law as outlined in the discussion, based on criminal decisions that have permanent legal force over the perpetrators

The needs to synchronize between the Criminal Code and the Electronic Transaction and Information Act, a clear and more specific rules are needed so that the offender is truly deterrent of the actions which has been committed and minimizes the existence of the same crime again.

The active role of the authorities is really required necessary to educate the public about the intricacy of the dangers of fraud through electronic media, if this is not realized it will cause many victims and appeals to the public to be more careful in conducting transactions through the electronic media so that this incident does not occur later on.

\section{REFERENCE}

Act No. 11 of 2008 regarding Electronic Transaction and Information

Ali, M. (2010). Pencemaran Nama Baik Melalui Sarana Informasi dan Transaksi Elektronik. Jurnal Konstitusi, 7 (6). Retrieved from https://jurnalkonstitusi.mkri.id/index.php/jk/article/view/255

Arnani, M. (2018). 16.000 Laporan Diterima CekRekening.id, Penipuan "Online" Capai 14.000". nasional.kompas.com. Retrieved from https://nasional.kompas.com/read/2018/09/11/15014481/16000laporan-diterima-cekrekeningid-penipuan-online-capai-14000

Chazawi, A., \& Ferdian, A. (2015). Penyerangan Terhadap Hukum Pemanfaatan Teknologi Informasi dan Transaksi Elektronik. Malang: Media Nusa Creative.

Danrivanto, B. (2017). Revolusi Cyberlaw Indonesia Pembaruan dan Revisi Undang-undang Informasi dan 
Transaksi Elektronik 2016. Bandung: PT Refika Aditama.

Kitab Undang-undang Hukum Pidana (KUHP)

Kurnia, T. S. (2016). Sistem Hukum Indonesia Sebuah Pemahaman Awal. Bandung: CV Mandar Maju.

Lamintang, P. A. F. (2011). Dasar-Dasar Hukum Pidana Indonesia. Bandung: PT. Citra Aditya Bakti.

Lay, A. (2011), Pre-Sales Consultant, Symantec, Peringkat Indonesia di Cyber Crime "Indonesia's ranking in Cyber Crime”. Jakarta: Raja Graffindo Persada.

Mahardhika, W. A. (2020). Tahun 2019, Ada 2.300 Laporan Penipuan Online. Kompas.com. Retrieved from https:/money.kompas.com/read/2020/01/23/193100826/tahun-2019-ada-2.300-laporan-penipuan-online.

Massudilawe. (2008). Undang-Undang Informasi dan Transaksi Elektronik. Bandung: Andi.

Moeljatno. (2007). KUHP (Kitab Undang-undang Hukum Pidana). Jakarta: Bumi Aksara.

Moeljatno. (2002). Asas-Asas Umum Pidana. Jakarta: PT. Rineka Cipta.

Prodjodikoro, W. (1989). Asas-Asas Hukum Pidana Indonesia. Bandung: PT. Eresco

Rahardjo, A. (2002). Cybercrime-Pemahaman dan Upaya Pencegahan Kejahatan Berteknologi. Bandung: Citra Aditya Bakti.

Ramli, A. (2004). Cyber Law Dan Haki-Dalam System Hukum Indonesia. Bandung: Rafika Aditama.

Suhariyanto, B. (2012). Tindak Pidana Teknologi Informasi. Jakarta: Raja Graffindo Persada.

Sugandhi. R. (1980). Kitab Undang-undang Hukum Pidana dan Penjelasannya. Surabaya: Usaha Nasional.

Soerodibroto, S. R. (1992). KUHP \& KUHAP. Jakarta: Rajawali Pers.

Soesilo. R. (1991). Kitab Undang-undang Hukum Pidana (KUHP) Serta Komentar-komentarnya Lengkap Pasal Demi Pasal. Bogor: Politeia. 